\title{
Street Theatre as an Educational Method for Agricultural Extension
}

\author{
Mohammad Reza Akbari* and Amir Alambeigi \\ Department of Agricultural Extension and Education, College of Agriculture and Natural Resources, University of Tehran, Karaj, Iran \\ *Corresponding Author: Mohammad Reza Akbari, Department of Agricultural Extension and Education, College of Agriculture and \\ Natural Resources, University of Tehran, Karaj, Iran.
}

Received: May 30, 2019; Published: June 11, 2019

DOI: 10.31080/ASAG.2019.03.0523

Agricultural extension is an informal educational system to facilitate socio-economic development in rural areas. This educational system formed and evolved in the west world, especially in the United States and as a social innovation diffused in the developing countries after World War II. Overall, this system services to different target groups such as farmers, rural women, and youth in order to improve human change (human change means change for better awareness, attitude, knowledge, intention, expectations, desires, behavior and wisdom). Since the education is the main instrument of human change, the agricultural extension apply a wide range of educational methods to achieve its goals.

Dependent on the dominant approach of extension system and characteristics of the target groups in a country, the extension system employ the different educational methods such as mass media and audio visual aids (radio, newspapers, print media and audio visual aids); group extension methods (demonstrations, field days, district fairs, farm walks, farmers rallies, folk media, group meetings, motivational tours, participatory technology development, training days and farmer field school); individual extension methods (individual farm visit); and participatory rural appraisal (PRA) methods [1]. But it seems that the agricultural extension system has faced with the new paths to evolve its services. Indeed, the socio-economic and climate changes put force on agriculture sector and natural resources, and in subsequent the extension system need to innovative methods for survival in this changing world.

Using the street theatre, as an innovation in agricultural extension system may make some opportunities for developing the services of this informal educational system. The street theatre was developed in various areas in order to modify social behaviors. This educational method has applied in different contexts such as medicine, health, policy and environment [2-5]. Therefore, the street theatre has high-capacity to human change and it seems that this educational method has potential to apply for target groups of agricultural extension. But this perspective just present the initial idea of using the street theatre in agricultural extension system and much research is needed for employing that in the real conditions.

\section{Bibliography}

1. B Swanson. Improving agricultural extension. Daya Books, (2005).

2. SK Ghosh., et al. "A community-based health education programme for bio-environmental control of malaria through folk theatre (Kalajatha) in rural India". Malaria Journal 5.1 (2006): 123.

3. C Johnston and D Bajrange. "Street theatre as democratic politics in Ahmedabad". Antipode 46.2 (2014): 455-476.

4. SM Metcalf and MM. Veiga. "Using street theatre to increase awareness of and reduce mercury pollution in the artisanal gold mining sector: a case from Zimbabwe". Journal of Cleaner Production 37 (2012): 179-184.

5. PJ Pelto and R Singh. "Community street theatre as a tool for interventions on alcohol use and other behaviors related to HIV risks". AIDS Behavior 14.1 (2010): 147-157.

\section{Volume 3 Issue 7 July 2019}

(c) All rights are reserved by Mohammad Reza Akbari and Amir Alambeigi. 